\title{
Effects of bamboo dominance and palm-heart harvesting on the phylogenetic structure of the seed and seedling communities in an old-growth Atlantic Forest
}

\section{Daniella Schweizer ${ }^{1}$, Débora Cristina Rother ${ }^{2,3 *}$, Ana Elena Muler², Ricardo Ribeiro Rodrigues², Marco Aurélio Pizo ${ }^{4}$ and Pedro H. S. Brancalion ${ }^{1}$}

\author{
1 Universidade de São Paulo, Escola Superior de Agricultura Luiz de Queiroz, Departamento de Ciências Florestais, Piracicaba, SP, Brazil \\ 2 Universidade de São Paulo, Escola Superior de Agricultura Luiz de Queiroz, Departamento de Ciências Biológicas, Piracicaba, SP, Brazil \\ ${ }^{3}$ Universidade Federal do ABC, Santo André, SP, Brazil \\ ${ }^{4}$ Universidade Estadual Paulista, Departamento de Zoologia, Rio Claro, SP, Brazil \\ (Received 2 February 2017; revised 26 August 2017; accepted 28 August 2017; first published online 26 September 2017)
}

\begin{abstract}
A comprehensive assessment of the effect of disturbances on tropical and subtropical forests is needed to better understand their impacts on forest structure and diversity. Although taxonomic and functional diversity measures have been successfully adopted in this context, phylogenetic diversity metrics are still poorly explored. We compared the phylogenetic structure of the seed rain and regenerating seedling community in patches of an old-growth Atlantic Forest remnant dominated or not by a ruderal bamboo species, Guadua tagoara. We sampled those patches before and after illegal harvesting of the palm Euterpe edulis thus assessing if the harvesting led to changes in the phylogenetic structure of the seed rain and the regenerating community in both patches. Bamboo-dominated patches showed a significantly higher presence of species in the seed rain that were more distantly related to each other in the phylogeny than expected by chance compared with patches without bamboos, but this difference disappeared after palm-heart harvesting. Contrary to what we expected, we did not find significant changes in the phylogenetic structure of seedlings before or after palm-heart harvesting. The phylogenetic structure at the tips of the phylogeny was random overall. The maintenance of a higher presence of far relatives in the phylogeny of the seedling community suggests, assuming trait conservatism, that despite bamboo dominance and palm-heart harvesting, functional diversity is being preserved at least in the early regenerating stages and in the time frame of the study. However, higher presence of pioneer taxa after palm-heart harvest indicates that this disturbance may lead old-growth areas to earlier successional stages.
\end{abstract}

Key Words: bamboo-dominated forest, community assembly, forest regeneration, palm-heart harvest, phylogenetic ecology

\section{INTRODUCTION}

Natural and anthropogenic disturbances may cause some ruderal species to dominate large forested areas and change forest structure (Farah et al. 2014, Schnitzer et al. 2000) and functioning (Muler et al. 2014). Native and exotic bamboo species are disturbance-adapted and profit from the opening of gaps in tropical forests (Griscom \& Ashton 2003). Bamboo negatively affects the recruitment of tree seedlings into older age categories, mainly through seedling mortality due to a falling branch, trunk or bamboo culm, leading to a self-perpetuating bamboo-

* Corresponding author. Email: deborarother@gmail.com dominated area with fewer trees in the canopy, lower density and basal area of regenerating trees, and a thicker litter depth compared with forest patches without bamboo (Griscom \& Ashton 2003, Guilherme et al. 2004, Lima et al. 2012, Rother et al. 2016a).

Under natural conditions, this proliferation of ruderal species occurs in isolated disturbed patches that gradually return to pre-disturbance conditions (Muler et al. 2014). However, the contemporary increase in humaninduced disturbances in tropical forests may favour the proliferation of ruderal species and amplify their impacts on community assembly during regeneration (ArroyoRodriguez et al. 2015, Asner et al. 2009, Laurance et al. 2014). The illegal harvesting of the endemic palm species, Euterpe edulis, in the Brazilian Atlantic forest has 
led to the creation of an increasing number of forest gaps that have been further colonized and dominated by the bamboo Guadua tagoara in some regions (Rother et al. 2009). Euterpe edulis plays an important role in forest ecosystem dynamics as a food source for birds and mammals that are important seed dispersers (Galetti et al. 1999, Rother et al. 2016b), thus negatively impacting seed rain taxonomic diversity (Muler et al. 2014). Despite previous studies on the impact of bamboo dominance and palm-heart harvesting on taxonomic diversity, a phylogenetic analysis has not been conducted. In this context, phylogenetic ecology frameworks complement taxonomic studies by linking species in a community with their evolutionary history (Gerhold et al. 2015, Swenson 2011, Tan et al. 2012). The loss of phylogenetic diversity and consequently of functional diversity would reduce forest stability and resilience to environmental changes such as those triggered by anthropogenic disturbances and a changing climate (Cadotte et al. 2012, Craven et al. 2016, Díaz \& Cabido 2001).

Our study was initially set up to compare the diversity and structure of old-growth forest patches of Atlantic forest dominated or not by bamboos, however, between the first and second census an unexpected harvest of palm-heart took place. As such our study evaluated changes in seed rain and seedling recruitment in a spatial (forest patches dominated or not by bamboos) and temporal (before and after palm-heart harvesting) context. We hypothesized that the seed rain and seedling communities on bamboo patches would show phylogenetic clustering (more close relatives than expected by chance). In addition, we also hypothesized that palm-heart harvesting would accentuate phylogenetic clustering in the seed rain in bamboo patches and lead to clustering in non-bamboo patches. For the seedling community, we assumed that palm-heart harvesting would lead to phylogenetic overdispersion (more distant relatives than expected by chance) in both bamboo-dominated and non-bamboo patches.

\section{METHODS}

\section{Study site}

This work was carried out in the Carlos Botelho State Park (CBSP) (37 $793 \mathrm{ha}, 24^{\circ} 00^{\prime}-24^{\circ} 15^{\prime} \mathrm{S}, 47^{\circ} 45^{\prime}-48^{\circ} 10^{\prime} \mathrm{W}$ ), São Paulo state, south-eastern Brazil. Carlos Botelho State Park is covered by dense tropical forest (Veloso \& Góes-Filho 1982). The local climate is classified as humid subtropical (CFA - Köppen system), an average annual temperature of $22^{\circ} \mathrm{C}$ and rainfall of $1584 \mathrm{~mm}$, concentrated from December to March (Muler et al. 2014). This protected area of the Atlantic forest has the highest levels of plant species richness of São Paulo state with about 1143 vascular species belonging to 140 families. The vegetation is characterized by the occurrence of the palm Euterpe edulis and almost one third of the area is covered by the native woody bamboo Guadua tagoara, forming a mosaic throughout the area.

Conservation efforts in the last decades have resulted in the establishment of a large network of protected areas in the coastal zone of south-eastern Brazil. This zone contains well-conserved areas of Atlantic forest, such as the Serra do Mar biogeographic region with $32.2 \%$ remaining forest cover (Ribeiro et al. 2009). Although deforestation has declined in this region, forest remnants are still submitted to chronic human-mediated disturbances caused by illegal palm-heart harvesting, which have led to the extirpation of the now threatened palm: Euterpe edulis.

\section{Data collection}

We collected data in a permanent plot of 10.24 ha composed by a grid of 256 subplots $(20 \times 20 \mathrm{~m})$, in which all individuals with $\mathrm{dbh}>4.8 \mathrm{~cm}$ were sampled. In the permanent plot we selected patches dominated and not dominated by the bamboo G. tagoara.

Seed rain - We collected seed rain data in two periods. In the first period (June 2004-May 2005), we randomly established $801-\mathrm{m}^{2}$ seed traps (40 in each bamboo and non-bamboo patches), made of wood and nylon screen and positioned $10 \mathrm{~cm}$ above ground (Rother et al. 2009). Traps were established with a minimum separation of $20 \mathrm{~m}$. After the first period, all individuals of the palm Euterpe edulis present in the study area were illegally harvested to collect palm-heart. Therefore, in the second period (January-December 2008) we evaluated the seed rain in bamboo and non-bamboo patches after the harvest of the palm-heart, using $610.25-\mathrm{m}^{2}$ seed traps (30 in bamboo and 31 in non-bamboo patches). These traps were also made of wood and nylon screen and installed $10 \mathrm{~cm}$ above ground.

Because of the spatial dynamics of the bamboo patches as a result of the death of culms and growth of new culms, the sampling points of the second period differed in number and partially differed in position from those sampled in the first period. We avoided resampling areas where bamboo had died. Death of G. tagoara occurs after its reproductive phase (Alves 2007). In both periods, seeds were collected monthly and identified at the species level whenever possible.

Seedlings - Following the same framework of the seed rain evaluation, we established $801-\mathrm{m}^{2}$ plots (40 in each forest patch type) adjacent to the seed traps to monitor seedling recruitment in the first period. In the second period, we established $610.25-\mathrm{m}^{2}$ plots in the 
patches (30 in bamboo and 31 in non-bamboo patches). In both periods, each seedling $\leq 0.30 \mathrm{~m}$ height was tagged, identified to species level whenever possible, and monitored monthly according to its survivorship.

\section{Data analysis}

We estimated the phylogenetic structure of the observed species in bamboo- and non-bamboo-dominated patches, before and after palm-heart harvest. We employed a local species pool surveyed by Lima et al. (2011) to generate the phylogenetic tree. We included in the species pool all species surveyed at our study sites that were not listed in Lima et al. (2011). We removed individuals that were not identified to the species level for the phylogenetic analysis. We compared 1027 seeds of 93 species in bamboo patches versus 1488 seeds of 131 in non-bamboo patches and 787 seedlings of 106 species versus 512 seedlings of 107 species in bamboo and non-bamboo patches, respectively.

We estimated the phylogenetic relationships among the species using the most recent angiosperms supertree, R20120829. To estimate the ages of the interior nodes and evenly space the nodes between them, we employed the Bladj algorithm from Phylocom and evolutionary ages published by Wikstrom et al. (2001). Before aging the file we checked for internal node inconsistencies as recommended by Gastauer \& Meira-Neto (2013). We estimated the evolutionary distance matrix between all species pairs observed in our patches using Phylomatic, an algorithm implemented in the software Phylocom (Webb et al. 2008).

We compared the phylogenetic structure of bamboodominated versus non-bamboo patches, before and after palm-heart harvest, using the net relatedness index (NRI) and the nearest taxon index (NTI) (Webb 2000). The first index estimates the mean pair-wise evolutionary distance among all species found in a given sample and compares this distance to the distance observed between the same number of taxa sampled at random from the species pool:

$$
\begin{aligned}
\mathrm{NRI}= & -1 \times\left(\left(\mathrm{MPD}_{\text {observedPD }}\right.\right. \\
& \left.\left.-\mathrm{Mean}_{\mathrm{MPD}} \mathrm{D}_{\text {nullPD }}\right) / \mathrm{sdMPD}_{\text {nullPD }}\right)
\end{aligned}
$$

The second index estimates the distance between one species and its closest relative in the community:

$$
\begin{aligned}
\mathrm{NTI}= & -1 \times\left(\left(\mathrm{MNTD}_{\text {observedPD }}\right.\right. \\
& \left.\left.- \text { Mean } \mathrm{MNTD}_{\text {nullPD }}\right) / \mathrm{sdMNTD}_{\text {nullPD }}\right)
\end{aligned}
$$

These measures assess if the phylogenetic dispersion in a community is greater or less than that expected at random given its species richness, meaning there are more or less closely related species than expected by chance. The values MPD and MNTD were compared to a null estimate generated by randomly sampling 9999 times from the local species pool, keeping observed plot abundance. Abundance-weighted phylogenetic indices are better than occurrence-based indices at capturing assembly processes such as environmental filtering or competition acting on a given community (Freilich \& Connolly 2015). We employed the randomization routine called 'taxa labels', which shuffles the labels of a phylogenetic distance matrix across all taxa, as a null model to estimate the random communities. This metric is considered as a conservative method for avoiding Type-I errors (Hardy 2008). In both cases, a positive index value indicates a higher presence of close relatives (phylogenetic clustering), whereas a negative value indicates a higher than expected presence of far relatives (phylogenetic overdispersion) in the plant community. To estimate which taxa in the communities were responsible for the observed phylogenetic pattern indicated by the indices we employed the function nodesig, implemented in the Picante package ( $\mathrm{R}$ version 3.1.1). We conducted all analyses separating seeds and seedlings.

\section{RESULTS}

Bamboo patches showed significant seed rain overdispersion (higher than expected presence of distant relatives), whereas non-bamboo patches showed a random phylogenetic structure (Figure 1a). Palm-heart harvesting changed the phylogenetic structure of the seed rain from significantly overdispersed in bamboo patches pre-harvest to random post-harvest as measured by the Net Relatedness Index (NRI, Figure 1a). Palmheart harvesting did not affect the phylogenetic structure of the seedling community, which was significantly overdispersed pre- and post-harvesting in both bamboodominated and non-dominated patches (Figure 1b). The phylogenetic structure at the tips of the phylogeny (NTI index) was random in bamboo- and non-bamboodominated patches, for both seeds and seedlings, and that structure did not change post-harvest (Figure 2).

Seeds of the pioneer species Cecropia glaziovii were more abundant than expected by chance in bamboo patches before palm-heart harvesting but no other taxa were more or less abundant than expected in either area. After the harvest, Cecropia and other pioneer taxa were more abundant than expected in the seed rain and seedlings of the palm, E. edulis, were also more abundant in bamboodominated patches (Table 1).

\section{DISCUSSION}

The use of a phylogenetic ecology framework for assessing the impacts of disturbances in the regenerating community in an Atlantic forest old-growth area 
Pre-harvest

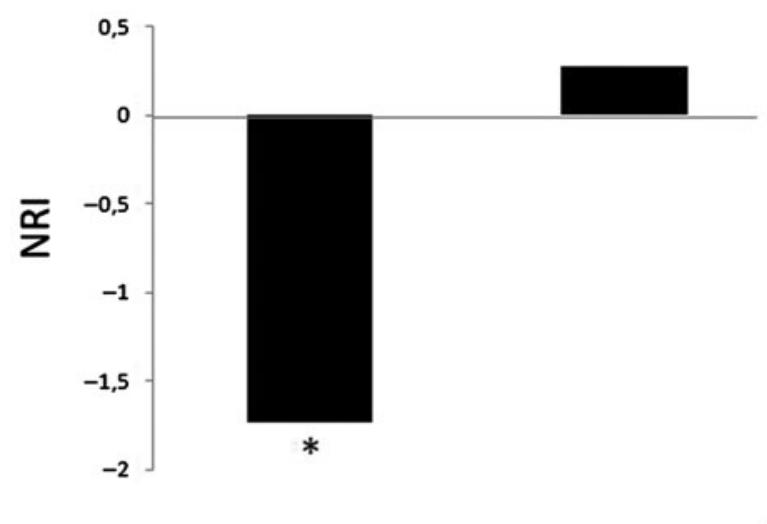

a

Post-harvest

b

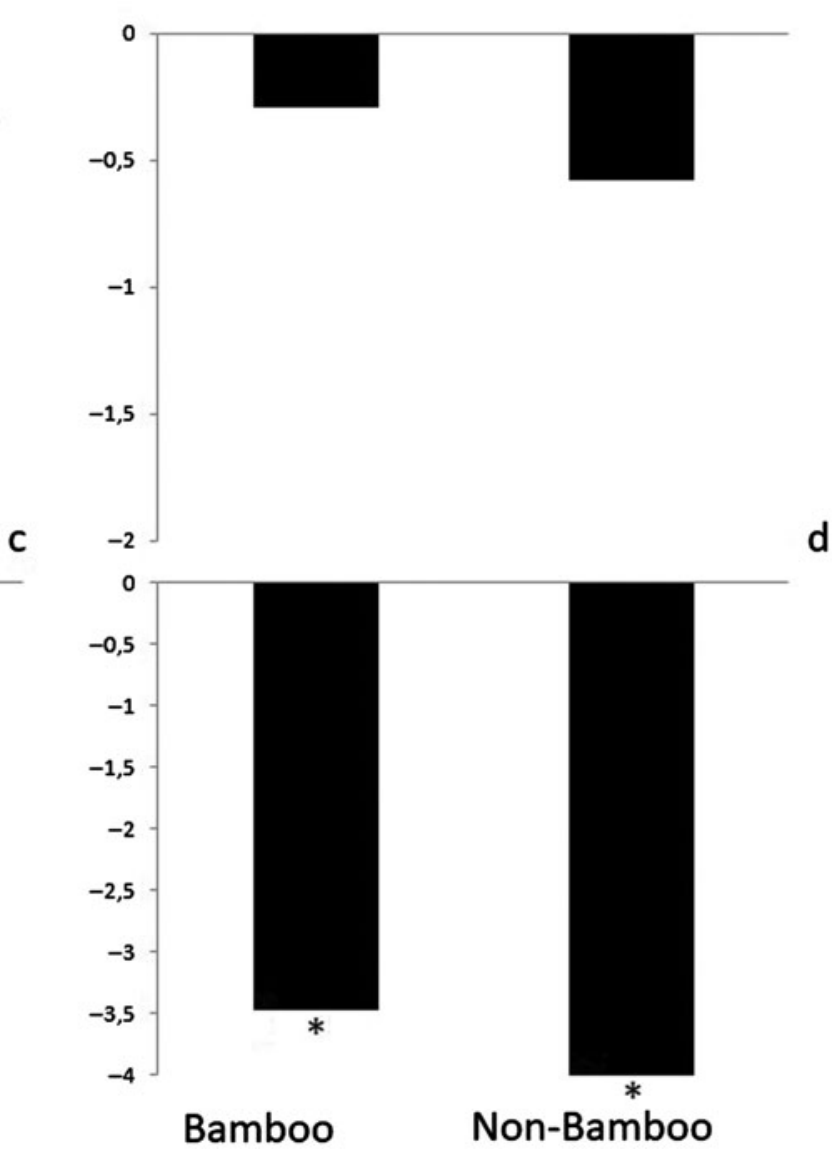

Figure 1. Net relatedness index (NRI) for seeds (a, b) and seedlings (c, d) at bamboo and non-bamboo patches pre-harvest (2004) and post-harvest (2008) of Euterpe edulis palm-heart, Carlos Botelho State Park, Sete Barras, São Paulo state, Brazil. Asterisks denote phylogenetic patterns that significantly differ from random. Data come from 80 seed and seedling collection areas in 2004 and 61 in 2008. The phylogenetic tree was estimated based on the most recent angiosperm tree found online, R20120829. We compared the seeds of 93 species in bamboo patches versus 131 in non-bamboo patches and the seedlings of 106 versus 107 species in bamboo and non-bamboo patches, respectively.

allowed us to distinguish the differential effects of bamboo dominance and palm-heart harvesting in the phylogenetic structure of seeds and seedlings. Contrary to what we expected, neither the presence of bamboo nor palm-heart harvesting significantly affected the phylogenetic patterns of the seed and seedling communities, which remained mostly random for the seed rain, except in the bamboo patches pre-harvest, and overdispersed in the seedling recruits for the Net Relatedness Index (NRI), and random for the seedlings in the Nearest Taxon Index (NTI). We did not observe the expected phylogenetic clustering that is exhibited in some plant communities with strong environmental filtering or after a disturbance (Dinnage 2009).

Greater bird species richness visiting bamboo patches (Rother et al. 2013) may explain the greater presence of far relatives in the seed rain and thus the significant overdispersed phylogenetic structure in bamboo-dominated patches. Frugivorous bird species visiting bamboo patches are not the same as the ones in non-bamboo patches (Rother et al. 2013), a difference that may be responsible for changes in the number of seeds deposited, the taxonomic and the phylogenetic composition of the seed rain. Contrary to our hypothesis, bamboo does not appear to be posing a negative environmental filter to the recruitment of a diverse seedlings assemblage. A strong environmental filter acting on conserved seed traits related to germination has been shown to lead to phylogenetically clustered communities (Vanderlook et al. 2012). Although bamboo litter may be harmful to woody species regeneration by establishing a physical barrier for seedling establishment and releasing allopathic substances shown to inhibit growth of native Atlantic forest species (GromboneGuaratini et al. 2009), this negative effect may be counterbalanced by higher habitat heterogeneity created 


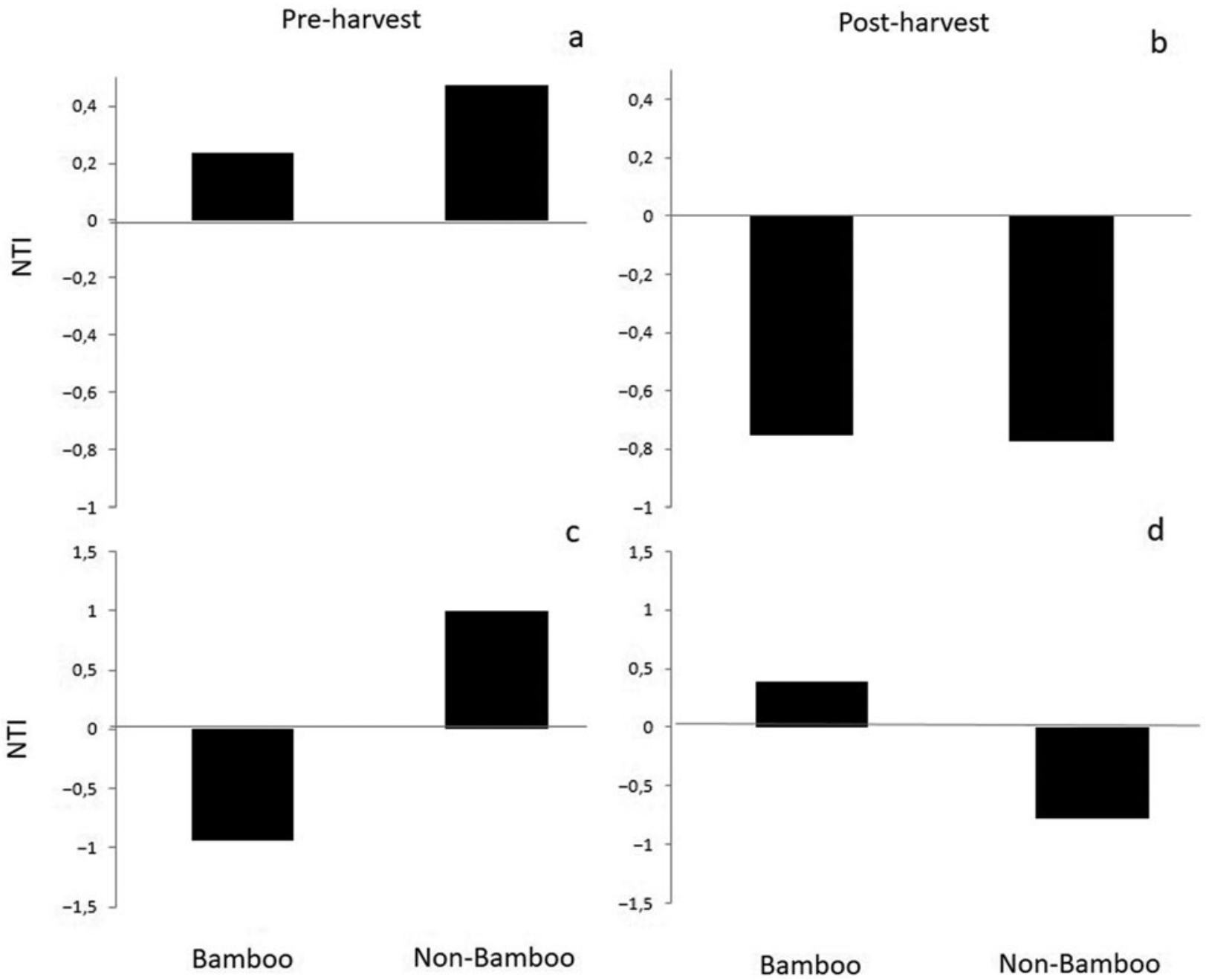

Figure 2. Nearest taxon index (NTI) for seeds (a, b) and seedlings (c, d) at bamboo and non-bamboo patches pre-harvest (2004) and post-harvest (2008) Euterpe edulis palm-heart harvesting, Carlos Botelho State Park, Sete Barras, São Paulo state, Brazil. The phylogenetic patterns observed did not differ from random. Data come from 80 seed and seedling collection areas in 2004 and 61 in 2008. The phylogenetic tree was estimated based on the most recent angiosperm tree found online, R20120829. We compared the seeds of 93 species in bamboo patches versus 131 in non-bamboo patches and the seedlings of 106 versus 107 species in bamboo and non-bamboo patches, respectively.

by differential light availability in the understorey (Stevens et al. 2012). We may observe a stronger negative effect of bamboo on later recruitment stages (Griscom \& Ashton 2003, Rother et al. 2016a). Guadua tagoara has been shown to function as a demographic bottleneck in later stages of Euterpe edulis recruitment, arresting its regeneration cycle (Rother et al. 2009). Similar effects may be expected for saplings and young trees. Other research has shown a lower adult tree density in bamboodominated patches in tropical forests (Fantini \& Guries 2007, Guilherme et al. 2004, Oliveira-Filho et al. 1994).

In addition, the overdispersion observed in the seedling communities, which did not differ between bamboodominated and non-dominated patches, could be due to the study sites being immersed in a matrix of old-growth, species-rich forest, thus with a great probability of arrival of species from distant clades. Strong environmental filters, such as the conditions present in abandoned agricultural sites, foster the colonization of close relatives due to the conservatism of traits related to seedling recruitment in disturbed patches (Baeten et al. 2015). On the other hand, overdispersed patterns as observed in the study sites resemble the patterns observed in oldsuccessional forests and in continuous forest stands ( $\mathrm{Li}$ et al. 2015, Munguía-Rosas et al. 2014). In sites with weak environmental filtering, it is expected that once species arrive at a site, distant relatives can more readily coexist due to greater niche and fitness differences than close relatives (Godoy et al. 2014).

Abundance of the pioneer taxa Cecropia glaziovii after palm-heart harvesting indicates that harvesting leads oldgrowth forest patches to early successional stages (Muler 
Table 1. Analysis of taxonomic nodes that significantly affected the phylogenetic structure of the seed rain and seedling community at bamboo and non-bamboo patches pre- (2004) and post- (2008) Euterpe edulis palm-heart harvesting, Carlos Botelho State Park, Sete Barras, São Paulo state, Brazil. Data come from 80 seed and seedling collection areas in 2004 (pre-harvest) and 61 in 2008 (post-harvest).

\begin{tabular}{|c|c|c|c|c|}
\hline Period & Area & Stage & Signal & Clade \\
\hline \multirow[t]{8}{*}{ Pre-harvest } & Bamboo & Seed & Less & None \\
\hline & & & More & Urticaceae (Cecropia glaziovii) \\
\hline & & Seedling & Less & None \\
\hline & & & More & None \\
\hline & Non-bamboo & Seed & Less & None \\
\hline & & & More & None \\
\hline & & Seedling & Less & None \\
\hline & & & More & None \\
\hline \multirow[t]{8}{*}{ Post-harvest } & Bamboo & Seed & Less & None \\
\hline & & & More & $\begin{array}{l}\text { Asteraceae (Mikania sp.), Urticaceae } \\
\quad \text { (Cecropia glaziovii) }\end{array}$ \\
\hline & & Seedling & Less & $\begin{array}{l}\text { Euphorbiaceae, Salicaceae (Casearia } \\
\text { sp.) }\end{array}$ \\
\hline & & & More & Arecaceae (Euterpe edulis) \\
\hline & Non-bamboo & Seed & Less & None \\
\hline & & & More & Urticaceae (Cecropia glaziovii) \\
\hline & & Seedling & Less & None \\
\hline & & & More & Araceae (Monstera adansonii) \\
\hline
\end{tabular}

et al. 2014, Tabanez \& Viana 2000). Cecropia glaziovii was the most abundant species sampled in the seed rain, in both patches, before palms were harvested, but seed number increased after harvesting (Muler et al. 2014). Cecropia species produce a large number of fruits and its seeds are dispersed by a wide variety of dispersers (birds, bats, primates, marsupials), therefore, it does not suffer from disturbances as much as other species do (Fleming \& Williams 1990). More seedlings of the palm $E$. edulis recruited after palm-heart than expected by chance, however, the observed decrease of around $90 \%$ of palm seeds after harvesting (Muler et al. 2014) indicates that this increase in seedling recruitment may come from the seed bank but that continued palm harvest will have strong effects on the future recruitment of the palm and the attraction of dispersers of other large-seeded species.

The phylogenetic analysis conducted in the present study complemented previous analyses regarding the effects of bamboo dominance and E. edulis harvesting on species taxonomic richness (Muler et al. 2014), showing that bamboo dominance and palm-heart harvesting not only affect the taxonomic diversity of the forest but also the phylogenetic structure, mainly of its seed rain, with implications for the stability and resilience of the forest in the future. Closely related taxa generally have a higher likelihood of sharing functional traits than further related ones (Manel et al. 2014), therefore the maintenance of overdispersed patterns in the seedling community indicate that despite bamboo dominance and palm-heart harvesting, functional diversity is being preserved at least at the early regenerating stages and in the time frame of the study. Despite challenges in phylogenetic trees resolution, this approach can be included in analyses of community composition as it contributes to a more comprehensive picture that can lead to further studies of processes of species assembly.

\section{ACKNOWLEDGEMENTS}

We gratefully acknowledge the staff of the Carlos Botelho State Park for permission to conduct our study in the park. We are especially grateful to Eric Teixeira, Paulo Cesar Teixeira, Henrique Teixeira and Natália Guerin for their help in the fieldwork. We really appreciate the help of Marcelo Pinho and Renato Augusto Ferreira de Lima in the seedlings identification. This study received financial support from the São Paulo Research Foundation (FAPESP) (\#1999/09635-0, \#2013/50718-5). Individual research grants were provided by the Brazilian National Research Council (CNPq) to DCR (\#143107/2006-2), MAP (\#303559/2008-0) and PHSB (\#304817/20155), and by FAPESP to DCR (\#2003/11073-7) and AEM (\#2007/06745-7).

\section{LITERATURE CITED}

ALVES, G. T. R. 2007. Aspectos da história de vida de Guadua tagoara (Nees) Kunth (Poaceae: Bambuseae) na Serra dos Órgãos, RJ. PhD Dissertation, Federal University of São Carlos, Brazil. https://repositorio.ufscar. br/handle/ufscar/1998. 
ARROYO-RODRIGUEZ, V., MELO, F. P., MARTINEZ-RAMOS, M., BONGERS, F., CHAZDON, R. L., MEAVE, J. A., NORDEN, N., SANTOS, B. A., LEAL, I. R. \& TABARELLI, M. 2015. Multiple successional pathways in human-modified tropical landscapes: new insights from forest succession, forest fragmentation and landscape ecology research. Biological Reviews 92:326-340.

ASNER, G. P., RUDEL, T. K., AIDE, T. M., DEFRIES, R. \& EMERSON, R. 2009. A contemporary assessment of change in humid tropical forests. Conservation Biology 23:1386-1395.

BAETEN, L., DAVIES, T. J., VERHEYEN, C., VAN CALSTER, H. \& VELLEND, M. 2015. Disentangling dispersal from phylogeny in the colonization capacity of forest understorey plants. Journal of Ecology 103:175-183.

CADOTTE, M. W., DINNAGE, R. \& TILMAN, D. 2012. Phylogenetic diversity promotes ecosystem stability. Ecology 93:S223-S233.

CRAVEN, D., FILOTAS, E., ANGERS, V. A. \& MESSIER, C. 2016. Evaluating resilience of tree communities in fragmented landscapes: linking functional response diversity with landscape connectivity. Diversity Distributions 22:505-518.

DÍAZ, S. \& CABIDO, M. 2001. Vive la différence: plant functional diversity matters to ecosystem processes. Trends in Ecology and Evolution 16:646-655.

DINNAGE, R. 2009. Disturbance alters the phylogenetic composition and structure of plant communities in an old field system. PLOS ONE $4: 1-9$.

FANTINI, A. C. \& GURIES, R. P. 2007. Forest structure and productivity of palmiteiro (Euterpe edulis Martius) in the Brazilian Mata Atlântica. Forest Ecology and Management 242:185-194.

FARAH, F. T., RODRIGUES, R. R., SANTOS, F. M., TAMASHIRO, J. Y., SHEPHERD, G. J., SIQUEIRA, T., BATISTA, J. L. F. \& MANLY, B. J. F. 2014. Forest destructuring as revealed by the temporal dynamics of fundamental species - case study of Santa Genebra Forest in Brazil. Ecological Indicators 37:40-44.

FLEMING, T. \& WILLIAMS, C. F. 1990. Phenology, seed dispersal, and recruitment in Cecropia peltata (Moraceae) in Costa Rican tropical dry forest. Journal of Tropical Ecology 6:163-178.

FREILICH, M. A. \& CONNOLLY, S. R. 2015. Phylogenetic community structure when competition and environmental filtering determine abundances. Global Ecology and Biogeography 42:1390-1400.

GALETTI, M., ZIPPARRO, V. \& MORELATTO, L. P. 1999. Fruit phenology and frugivory on the palm Euterpe edulis in a lowland Atlantic forest of Brazil. Ecotropica 5:115-122.

GASTAUER, M. \& MEIRA-NETO, J. A. A. 2013. Avoiding inaccuracies in tree calibration and phylogenetic community analysis using Phylocom 4.2. Ecological Informatics 15:85-90.

GERHOLD, P., CAHILL, J. F., WINTER, M., BARTISH, I. V. \& PRINZING, A. 2015. Phylogenetic patterns are not proxies of community assembly mechanisms (they are far better). Functional Ecology 29:600-614.

GODOY, O., KRAFT, N. J. B. \& LEVINE, J. M. 2014. Phylogenetic relatedness and the determinants of competitive outcomes. Ecology Letters 17:836-844.

GRISCOM, B. W. \& ASHTON, M. S. 2003. Bamboo control of forest succession: Guadua sarcocarpa in Southeastern Peru. Forest Ecology and Management 175:445-454.
GROMBONE-GUARATINI, M. T., JESSEN, R. C., CARDOSO-LOPES, E. M. \& TORRES, L. M. B. 2009. Allelopathic potential of Aulonemia aristulata (Doll) MacClure, a native bamboo of Atlantic Rain Forest. Allelopathy Journal 24:183-190.

GUILHERME, F. A. G., OLIVEIRA-FILHO, A. T., APPOLINÁRIO, V. \& BEARZOTI, E. 2004. Effects of flooding regime and woody bamboos on tree community dynamics in a section of tropical semideciduous forest in South-Eastern Brazil. Plant Ecology 174:19-36.

HARDY, O. J. 2008. Testing the spatial phylogenetic structure of local communities: statistical performances of different null models and test statistics on a locally neutral community. Journal of Ecology 96:914-926.

LAURANCE, W. F., ANDRADE, A. S., MAGRACH, A., CAMARGO, J. L. C., VALSKO, J. J., CAMPBELL, M., FEARNSIDE, P. M., EDWARDS, W., LOVEJOY, T. E. \& LAURANCE, S. G. 2014. Long-term changes in liana abundance and forest dynamics in undisturbed Amazonian forests. Science 95:1604-1611.

LI, S. P., CADOTTE, M. W., MEINERS, S. J., HUA, Z., JIANG, L. \& SHU, W. S. 2015. Species colonization, not competitive exclusion, drives community overdispersion over long-term succession. Ecology Letters 18:964-973.

LIMA, R. A. F., DITTRICH, V. A. O., SALINO, A. B., BREIER, T. B. \& AGUIAR, O. T. 2011. Flora vascular do Parque Estadual Carlos Botelho, São Paulo, Brasil. Biota Neotropica 11:173-214.

LIMA, R. A. F., ROTHER, D. C., MULER, A. E., LEPSCH, I. F. \& RODRIGUES, R. R. 2012. Bamboo overabundance alters forest structure and dynamics in the Atlantic Forest hotspot. Biological Conservation 147:32-39.

MANEL, S., COUVREUR, T. L. P., MUNOZ, F., COUTERON, P., HARDY, O. J. \& SONKÉ, B. 2014. Characterizing the phylogenetic tree community structure of a protected tropical rain forest area in Cameroon. PLoS ONE 9:1-12.

MULER, A. E., ROTHER, D. C., BRANCALION, P. H. S., NAVES, R. P., RODRIGUES, R. R. \& PIZO, M. A. 2014. Can overharvesting of a non-timber-forest-product change the regeneration dynamics of a tropical rainforest? The case study of Euterpe edulis. Forest Ecology and Management 324:117-125.

MUNGUÍA-ROSAS, M. A., JURADO-DZIB, S. G., MEZETA-COB, C. R., MONTIEL, S., ROJAS, A. \& PECH-CANCHÉ, J. M. 2014. Continuous forest has greater taxonomic, functional, and phylogenetic plant diversity than an adjacent naturally fragmented forest. Journal of Tropical Ecology 30:323-333.

OLIVEIRA-FILHO, A. T., VILELA, E. A., GAVILANES, M. L. \& CARVALHO, D. A. 1994. Effect of flooding regime and understorey bamboos on the physiognomy and tree species composition of a tropical semideciduous forest in southeastern Brazil. Plant Ecology 113:99-124.

Ribeiro, M. C., METZGer, J. P., MARTENSEN, A. C., PONZONI, F. J. \& HIROTA, M. M. 2009. The Brazilian Atlantic Forest: how much is left, and how is the remaining forest distributed? Implications for conservation. Biological Conservation 142:11411153.

ROTHER, D. C., RODRIGUES, R. R. \& PIZO, M. A. 2009. Effects of bamboo stands on seed rain and seed limitation in a rainforest. Forest Ecology and Management 257:885-892. 
ROTHER, D. C., ALVES, K. J. F. \& PIZO, M. A. 2013. Avian assemblages in bamboo and non-bamboo habitats in a tropical rainforest. Emu 113:52-61.

ROTHER, D. C., RODRIGUES, R. R. \& PIZO, M. A. 2016a. Bamboo thickets alter the demographic structure of Euterpe edulis population: a keystone, threatened palm species of the Atlantic forest. Acta Oecologica 70:96-102.

ROTHER, D. C., PIZO, M. A. \& JORDANO, P. 2016b. Variation in seed dispersal effectiveness: the redundancy of consequences in diversified tropical frugivore assemblages. Oikos 125:336-342.

SCHNITZER, S. A., DALLING, J. W. \& CARSON, W. P. 2000. The impact of lianas on tree regeneration in canopy gaps: evidence for an alternative pathway of gap-phase regeneration. Journal of Ecology 88:655-666.

STEVENS, R. D., GAVILANEZ, M. M., TELLO, J. S. \& RAY, D. A. 2012. Phylogenetic structure illuminates the mechanistic role of environmental heterogeneity in community organization. Journal of Animal Ecology 81:455-462.

SWENSON, N. 2011. The role of evolutionary processes in producing biodiversity patterns, and the interrelationships between taxonomic, functional, and phylogenetic biodiversity. American Journal of Botany 98:472-480.
TABANEZ, A. A. J. \& VIANA, V. M. 2000. Patch structure within Brazilian Atlantic Forest fragments and implications for conservation. Biotropica 32:925-933.

TAN, J. Q., PU, Z. C., RYBERG, W. A. \& JIANG, L. 2012. Species phylogenetic relatedness, priority effects, and ecosystem functioning. Ecology 93:1164-1172.

VANDERLOOK, F., VERDÚ, M. \& HONNAY, O. 2012. The role of seed traits in determining the phylogenetic structure of temperate plant communities. Annals of Botany 110:1-8.

VELOSO, H. P. \& GÓES FILHO, L. 1982. Fitogeografia brasileira: classificação fisionômica-ecológica da vegetação neotropical. Boletim Técnico Projeto RADAMBRASIL. Série Vegetação, 1. Ministério das Minas e Energia, Salvador.

WEBB, C. O. 2000. Exploring the phylogenetic structure of ecological communities: an example for rain forest trees. American Naturalist 156:145-155.

WEBB, C. O., ACKERLY, D. D. \& KEMBEL, S. W. 2008. Phylocom: software for the analysis of phylogenetic community structure and trait evolution. Bioinformatics 24:2098-2100.

WIKSTROM, N., SAVOLAINEN, V. \& CHASE, M. W. 2001. Evolution of the angiosperms: calibrating the family tree. Proceedings of the Royal Society of London 268:2211-2220. 